\title{
PENGARUH PEMAHAMAN, KESADARAN, KUALITAS PELAYANAN DAN KETEGASAN SANKSI TERHADAP KEPATUHAN WPOP
}

\author{
LAURA \\ IMAN AKHADI \\ Sekolah Tinggi IImu Ekonomi Trisakti, Jl. Kyai Tapa No. 20, Jakarta, Indonesia \\ iman.akh@gmail.com
}

\begin{abstract}
This study aims to obtain empirical evidence and examine the influence of independent variables, namely understanding, awareness, quality of services, strictness of sanction, modernization of the tax administration system and tax socialization. On the dependent variable, namely compliance individual taxpayers. Taxpayers registered in DKI Jakarta are the population in this study. Meanwhile, this study used a sample of 104 respondents, namely individual taxpayers who work as an entrepreneur and have NPWP which is in West Jakarta region. The sampling technique researchers use in one type of non-probability sampling, namely convenience sampling or accidental sampling. The instrument used to collect data in this study was a closed questionnaire. The result given in this research are; modernization of tax administration have an influence on compliance of individual taxpayers. While understanding, awareness, quality of services, strictness of sanction and tax socialization do not have an influence on compliance of individual taxpayers.
\end{abstract}

Keywords: Understanding, awareness, quality of services, strictness of sanction, modernization of tax administration system, tax socialization, compliance of individual taxpayers.

Abstrak: Penelitian ini bertujuan untuk mendapatkan bukti empiris dan meneliti pengaruh dari variabel independen yaitu pemahaman, kesadaran, kualitas pelayanan, ketegasan sanksi, modernisasi sistem administrasi perpajakan, dan sosialisasi perpajakan terhadap variabel dependen yaitu kepatuhan wajib pajak orang pribadi. Wajib pajak yang terdaftar di DKI Jakarta merupakan populasi dalam penelitian ini. Sampel yang digunakan dalam penelitian ini sebanyak 104 responden yaitu wajib pajak orang pribadi yang bekerja sebagai wiraswasta yang memiliki NPWP di wilayah Jakarta Barat. Teknik pengambilan sampel yang digunakan merupakan salah satu jenis non-probability sampling yaitu convenience sampling atau accidental sampling. Instrumen yang digunakan untuk mengumpulkan data dalam penelitian ini adalah kuesioner yang bersifat tertutup. Hasil yang diberikan dalam penelitian ini adalah modernisasi sistem administrasi perpajakan memiliki pengaruh terhadap kepatuhan wajib pajak orang pribadi. Sedangkan pemahaman, kesadaran, kualitas pelayanan, ketegasan sanksi dan sosialisasi perpajakan tidak memiliki pengaruh terhadap kepatuhan wajib pajak orang pribadi.

Kata Kunci: Pemahaman, kesadaran, kualitas pelayanan, ketegasan sanksi, modernisasi sistem administrasi perpajakan, sosialisasi perpajakan, kepatuhan wajib pajak orang pribadi 


\section{PENDAHULUAN}

Penerimaan perpajakan merupakan salah satu pilar utama penerimaan negara dalam APBN. Hal ini sejalan dengan amanat dalam UU No 17 Tahun 2003 tentang Keuangan Negara Pasal 8 Huruf e yang menyatakan bahwa penerimaan perpajakan merupakan salah satu unsur pengemban tugas dalam pemungutan pendapatan negara, diharapkan mampu memenuhi kebutuhan penyelenggaraan pemerintahan negara sesuai dengan kemampuan dalam menghimpun pendapatan negara. Salah satu system pemungutan pajak yang berlaku di Indonesia adalah Self Assessment System, dimana wajib pajak diberikan kepercayaan untuk menghitung, memperhitungkan, membayar dan melaporkan kewajiban perpajakannya. Sehingga dengan system tersebut, diharapkan wajib pajak secara sadar dan penuh tanggung jawab dapat melaksanakan kewajiban perpajakannya sesuai dengan ketentuan perundangan yang berlaku.

Kesadaran wajib pajak dengan memberikan dana dalam pelaksanaan fungsi perpajakan dengan cara wajib pajak sendiri yang membayar pajak tepat waktu dan tepat jumlah akan berpengaruh terhadap peningkatan kepatuhan wajib pajak itu sendiri. Kualitas pelayanan dan ketegasan sanksi yang sesuai dengan aturan perpajakan yang berlaku agar meningkatkan kepatuhan wajib pajak dalam memenuhi kewajiban perpajakannya. Adapun, modernisasi sistem administrasi perpajakan yang dilakukan pemerintah selain untuk meningkatkan kepatuhan wajib pajak tetapi juga untuk menunjukkan adanya perubahan paradigma tentang perpajakan yang lebih baik sesuai dengan Undang-Undang yang berlaku. Dengan diadakannya penyuluhan perpajakan baik secara langsung dan secara tidak langsung, masyarakat akan mendapatkan pemahaman dan informasiinformasi lebih tentang ketentuan dan aturan perpajakan yang berlaku sehingga masyarakat dapat melakukan kewajiban perpajakannya secara penuh.
Penelitian ini dikembangkan dari penelitian Subarkah dan Dewi (2017) dengan menambahkan dua variabel independen baru dan memiliki wilayah penelitian yang berbeda dengan penelitian sebelumnya. Penelitian ini bertujuan untuk mengetahui variabel apa saja yang berpengaruh maupun tidak berpengaruh terhadap kepatuhan wajib pajak orang pribadi.

\section{Kepatuhan wajib pajak}

Sistem pemungutan pajak dapat dikatakan sebagai metode pengelolaan utang pajak yang dibayarkan oleh wajib pajak agar dapat masuk kedalam kas negara. Terdapat 3 sistem pemungutan pajak menurut Mardiasmo (2016) yaitu Official Assessment System, Self Assessment System dan Withholding System. Hal ini mengingatkan bahwa sistem perpajakan di Indonesia menganut Self Assessment System, dimana kepatuhan wajib pajak ini menjadi aspek yang sangat penting dimana dalam prosesnya wajib pajak itu sendiri diberikan kepercayaan dalam menghitung, membayar, dan melaporkan kewajiban perpajakannya sendiri.

\section{Pemahaman}

Dengan adanya pemahaman atau pengetahuan perpajakan bertujuan untuk meningkatkan kepatuhan wajib pajak dalam melakukan kewajiban perpajakannya serta untuk tercapainya tujuan pembangunan bagi kesejahteraan masyarakat. Wajib pajak juga dapat berkomunikasi dengan Account Representatives mengenai hal-hal perpajakan terbaru, agar wajib pajak akan mengerti dan dapat mengambil peran aktif dalam memenuhi kewajiban perpajakannya.

Masruroh dan Zulaikha (2013), Lydiana (2018), serta Naufal dan Setiawan (2018) melakukan penelitian yang menyatakan bahwa pemahaman memiliki pengaruh terhadap kepatuhan wajib pajak orang pribadi. Namun, penelitian yang dilakukan oleh Subarkah dan Dewi (2017) menyatakan bahwa tidak terdapat pengaruh yang signifikan pemahaman terhadap kepatuhan wajib pajak ornag pribadi. 
Berdasarkan penjelasan diatas, maka dapat dirumuskan hipotesis sebagai berikut:

$\mathrm{H}_{1}$ : Terdapat pengaruh pemahaman terhadap kepatuhan wajib pajak orang pribadi.

\section{Kesadaran}

Pemerintah sangat mengharapkan adanya kesadaran dari wajib pajak itu sendiri seiring dengan diterapkannya Self Assessment System yang ditunjukkan untuk melaksanakan tanggung jawab perpajakannya sendiri secara penuh. Dengan demikian, kesadaran wajib pajak pun tinggi atau meningkat akan memberikan pengaruh kepada peningkatan terhadap kepatuhan wajib pajak yang lebih baik. Penelitian yang dilakukan oleh Subarkah dan Dewi (2017), Yusnidar (2015), Jotopurnomo dan Mangoting (2013) serta Tiraada (2013) menunjukkan hasil adanya pengaruh kesadaran terhadap kepatuhan wajib pajak orang pribadi. Namun, Lydiana (2018) menunjukkan hasil penelitian bahwa kesadaran tidak memberikan pengaruh terhadap kepatuhan wajib pajak orang pribadi. Berdasarkan penjelasan diatas, hipotesis dapat dirumuskan sebagai berikut:

$\mathrm{H}_{2}$ : Terdapat pengaruh dari kesadaran terhadap kepatuhan wajib pajak orang pribadi.

\section{Kualitas Pelayanan}

Suatu bentuk perilaku terhadap orang lain yang dapat ditunjukkan untuk memberikan informasi, fasilitas, motivasi dan sarana disebut pelayanan. Dimana, kualitas pelayanan yang akan diberikan oleh petugas pajak dapat memenuhi atau melebihi harapan wajib pajak, maka pelayanan yang diberikan berkualitas sehingga akan mendorong kepatuhan wajib pajak dalam memenuhi kewajiban perpajakannya. Demikian pula, pelayanan yang diberikan petugas pajak tidak memenuhi atau tidak dapat melebihi harapan wajib pajak, maka pelayanan yang diberikan pun tidak berkualitas.
Penelitian yang dilakukan oleh Subarkah dan Dewi (2017), Jotopurnomo dan Mangoting (2013), Lubis (2018) menunjukkan hasil bahwa kualitas pelayanan memberikan pengaruh yang signifikan terhadap kepatuhan wajib pajak orang pribadi. Namun, penelitian yang dilakukan Masruroh dan Zulaikha (2013), Tiraada (2013) mendapatkan hasil yang berbeda bahwa kualitas pelayanan tidak berpengaruh terhadap kepatuhan wajib pajak orang pribadi. Berdasarkan penjelasan diatas, maka dapat dirumuskan hipotesis sebagai berikut:

$\mathrm{H}_{3}$ : Terdapat pengaruh dari kualitas pelayanan terhadap kepatuhan wajib pajak orang pribadi.

\section{Ketegasan Sanksi}

Pada kenyataannya, masih banyak wajib pajak yang belum atau tidak memenuhi kewajiban perpajakannya. Tindakan tersebut salah satunya ialah dengan melalui pemberian sanksi kepada wajib pajak yang tidak patuh atas kewajiban perpajakannya. Sanksi yang diberikan dapat seperti sanksi administrasi yang berupa bunga, denda dan kenaikan. Adapun sanksi pidana yang berupa hukuman penjara atau kurungan. Dengan demikian, tingkat kepatuhan akan menjadi lebih baik dan meningkat jika wajib pajak yang tidak patuh dan yang kepatuhannya tergolong rendah akan diberikan sanksi perpajakan yang berlaku.

Penelitian yang dilakukan oleh Subarkah dan Dewi (2017), Jotopurnomo dan Mangoting (2013), serta Lubis (2018) menunjukkan hasil terdapat pengaruh yang signifikan ketegasan sanksi terhadap kepatuhan wajib pajak orang pribadi. Namun, penelitian yang dilakukan Masruroh dan Zulaikha (2013), Tiraada (2013) serta Tahar dan Rachman (2014) menunjukkan hasil penelitian yang berbeda yaitu kualitas pelayanan tidak memberikan pengaruh terhadap kepatuhan wajib pajak orang pribadi. Berdasarkan penjelasan diatas, maka dapat dirumuskan hipotesis sebagai berikut: 
$\mathrm{H}_{4}$ : Terdapat pengaruh dari ketegasan sanksi terhadap kepatuhan wajib pajak orang pribadi.

\section{Modernisasi Sistem Administrasi Perpajakan}

Mengutip pendapat dari Rahayu (2017, 119) menyatakan bahwa bagian dari reformasi perpajakan di Indonesia yang dibangun secara bertahap dalam aturan perpajakan, kebijakan maupun pengawasan merupakan sistem administrasi perpajakan. Dimana, dengan menerapkan sistem administrasi perpajakan yang transparan dan akuntabel dengan memanfaatkan sistem informasi teknologi informasi komunikasi yang andal dan yang terkini merupakan definisi dari Good Governance. Dengan demikian, pemerintah melaksanakan sistem modernisasi administrasi perpajakan ini untuk mendukung program keterbukaan dan transparasi guna untuk mencegah adanya atau terjadinya kolusi, korupsi dan nepotisme. Modernisasi sistem administrasi perpajakan ini diharapkan dapat sejalan dengan tingkat kepatuhan wajib pajak yaitu dalam mendaftarkan diri, melaporkan, menyetorkan serta melakukan perhitungan dan membayar tunggakan pajak guna untuk mencapai kewajiban perpajakannya.

Penelitian sebelumnya yang dilakukan oleh Sarunan (2015), Kurniawan (2018) serta Utari et al. (2020) menunjukkan hasil bahwa adanya pengaruh positif modernisasi sistem administrasi perpajakan terhadap kepatuhan wajib pajak ornag pribadi. Namun, penelitian yang dilakukan oleh Rahayu dan Lingga (2009) serta Arifah et al. (2017) menunjukkan hasil yang berbeda bahwa tidak terdapat pengaruh signifikan modernisasi sistem administrasi perpajakan terhadap kepatuhan wajib pajak orang pribadi. Berdasarkan penjelasan diatas, dirumuskan hipotesis sebagai berikut:

$\mathrm{H}_{5}$ : Terdapat pengaruh dari modernisasi sistem administrasi perpajakan terhadap kepatuhan wajib pajak orang pribadi.

\section{Sosialisasi Perpajakan}

Mengutip pendapat dari Naufal dan Setiawan (2018) bahwa hal penting dalam upaya peningkatan kepatuhan wajib pajak dalam melakukan perpajakannya merupakan sosialisasi. Kegiatan dalam melakukan atau memberdayakan perpajakan melalui informasi atau pembinaan agar masyarakat lebih paham dan mengerti perpajakan sesuai dengan peraturan perpajakan disebut sosialisasi pajak atau nama lain disebut penyuluhan pajak. Dengan demikian, sosialisasi perpajakan sangat berguna bagi masyarakat untuk lebih mempunyai kesadaran dan pengetahuan tentang bergunanya perpajakan untuk kemakmuran negara.

Penelitian dari Naufal dan Setiawan (2018), Ananda et al. (2015), serta Nindya dan Wibisono (2019) menunjukkan hasil bahwa sosialisasi perpajakan berpangaruh positif dan signifikan terhadap kepatuhan wajib pajak orang pribadi. Namun, hasil penelitian yang dilakukan oleh Lianty dan Hapsari (2017), Siahaan dan Halimatusyadiah (2018), serta Winerungan (2013) menunjukkan hasil bahwa sosialisasi tidak berpengaruh terhadap kepatuhan wajib pajak orang pribadi. Dari penjelasan diatas, maka dirumuskan hipotesis sebagai berikut:

$\mathrm{H}_{6}$ : Terdapat pengaruh dari sosialisasi perpajakan terhadap kepatuhan wajib pajak orang pribadi.

Model penelitian menggambarkan hubungan antara variabel-variabel independen yang digunakan dalam penelitian berupa Pemahaman, Kesadaran, Kualitas Pelayanan, Ketegasan Sanksi, Modernisasi Sistem Administrasi Perpajakan dan Sosialisasi Perpajakan dengan variabel dependen berupa Tingkat Kepatuhan Wajib Pajak. Berdasarkan hipotesis yang telah diuraikan diatas, peneliti akan melakukan pengujian secara statistik apakah variabel-variabel independen memberikan pengaruh yang signifikan terhadap variabel dependen baik secara simultan ataupun secara individu. Adapun model penelitian untuk menggambarkan hubungan variabel independen dengan variabel dependen dapat digambarkan gambar 1 sebagai berikut: 


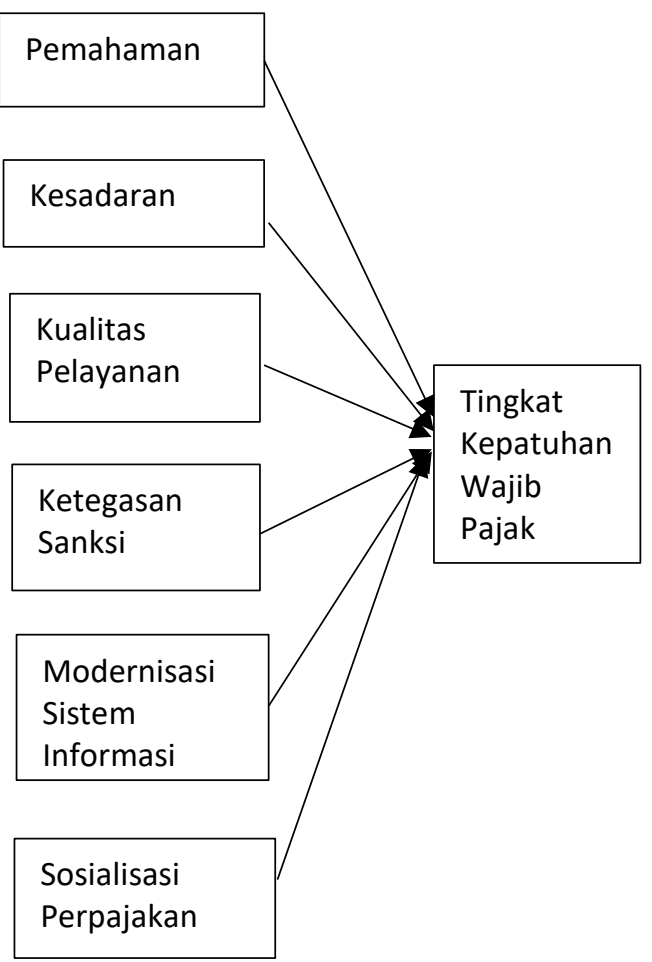

Gambar 1 Model Penelitian

\section{METODE PENELITIAN}

Data primer merupakan data yang akan digunakan dalam penelitian ini. Data primer diperoleh secara langsung dari responden itu sendiri dengan melalui kuesioner yang bersifat tertutup. Serta menggunakan metode penelitian kuantitatif. Populasi dalam penelitian ini adalah wajib pajak yang terdaftar di DKI Jakarta. Sampel dalam penelitian ini menggunakan 104 responden yang merupakan wajib pajak orang pribadi yang bekerja sebagai wiraswasta yang memiliki NPWP (Nomor Pokok Wajib Pajak) di wilayah Jakarta Barat. Teknik pengambilan sampel yang peneliti gunakan ialah salah satu jenis non-probability sampling yaitu convenience sampling atau accidental sampling. Pada bulan Maret 2020, peneliti menyebarkan kuesioner secara langsung berupa kertas yang berisi beberapa butir pernyataan kepada responden dan juga menyebarkan secara elektronik yang disebut Google Form atau Google Formulir serta meminta bantuan kepada kerabat untuk menyebarkan kuesioner tersebut.

Tabel 1 Persentase Kuesioner Penelitian

\begin{tabular}{|lcc|}
\hline \multicolumn{1}{|c}{ Keterangan } & $\begin{array}{c}\text { Jumlah } \\
\text { Responden }\end{array}$ & $\begin{array}{c}\text { Persentase } \\
(\%)\end{array}$ \\
\hline Kuesioner yang disebarkan secara langsung (Kertas) & 6 & 4,51 \\
Kuesioner yang disebarkan secara langsung (Google & 127 & 95,49 \\
Form) & & \\
Kuesioner yang tidak valid (Kertas) & $(1)$ & 0,75 \\
Kuesioner yang tidak valid (Google Form) & $(28)$ & 21,05 \\
Total kuesioner yang tidak dapat digunakan & $(29)$ & $(21,80)$ \\
\hline Total kuesioner yang dapat digunakan & 104 & 78,20 \\
\hline
\end{tabular}

Sumber: Diolah oleh peneliti

Kuesioner yang telah disebarkan merupakan kuesioner yang dikumpulkan secara langsung atau dalam bentuk kertas sebanyak 6 kuesioner atau sebesar $4,51 \%$ dan dalam bentuk Google Form atau Google Formulir sebanyak 127 kuesioner atau sebesar 95,49\%. Serta adanya ketidaksesuaian respon dengan kriteria objek penelitian yang disebarkan dalam bentuk kertas sebanyak 1 kuesioner atau sebesar $0,75 \%$ dan dalam bentuk Google Form atau Google Formulir sebanyak 28 kuesioner atau sebesar $21,05 \%$. Hal ini menyebabkan ketidaksesuaian respon yang dikarenakan tidak memiliki NPWP atau NPWP yang tidak berada 
di wilayah Jakarta Barat serta jenis pekerjaan yang tidak sesuai dengan kriteria objek penelitian. Oleh karena itu, kuesioner yang dapat digunakan dalam penelitian ini adalah 104 sebanyak 104 responden atau sebesar $78,20 \%$. (Tabel 1).

\section{HASIL PENELITIAN}

Berikut merupakan hasil statistik deskriptif responden berupa data indentitas yang terdiri dari jenis kelamin, umur, status, pendidikan dan pekerjaan responden serta hasil pengujian statistik deskriptif untuk variabel yang digunakan dalam penelitian ini. (Tabel 1 dan 2)

Tabel 2 Statistik Deskriptif Responden

\begin{tabular}{llcc}
\hline \multicolumn{1}{c}{ Keterangan } & Lumlah & $\begin{array}{c}\text { Jumentase } \\
\text { (Responden) }\end{array}$ & $\begin{array}{c}\text { Persentase } \\
\text { (\%) }\end{array}$ \\
\hline \multirow{2}{*}{ Jenis Kelamin } & Laki-laki & 42 & 40,4 \\
& Perempuan & 64 & 59,6 \\
\cline { 2 - 4 } & Total & 104 & 100 \\
\hline \multirow{2}{*}{ Status } & Kawin & 25 & 24,0 \\
& Belum Kawin & 79 & 76,0 \\
\cline { 2 - 4 } & Total & 104 & 100 \\
\hline Umur & 21-35Tahun & 83 & 79,8 \\
& 36-45Tahun & 5 & 4,8 \\
& 46-55Tahun & 13 & 12,5 \\
& $\geq 56 T a h u n$ & 3 & 2,9 \\
\cline { 2 - 4 } & Total & 104 & 100 \\
\hline Pendidikan & SMA & 22 & 21,2 \\
& Diploma & 9 & 8,7 \\
& Sarjana & 72 & 69,2 \\
& Pascasarjana & 1 & 1,0 \\
\cline { 2 - 4 } & Total & 104 & 100 \\
\hline Pekerjaan & Wiraswasta & 104 & \\
\hline
\end{tabular}

Sumber: Diolah oleh peneliti

Tabel 3 Statistik Deskriptif Variabel

\begin{tabular}{|c|c|c|c|c|c|}
\hline Variabel & $\mathbf{N}$ & Minimum & Maximum & $\begin{array}{l}\text { Rata-rata } \\
\text { (Mean) }\end{array}$ & $\begin{array}{l}\text { Standa } \\
\text { Devias }\end{array}$ \\
\hline Pemahaman & 104 & 11 & 25 & 20,08 & 2,932 \\
\hline Kesadaran & 104 & 12 & 25 & 20,69 & 3,169 \\
\hline Kualitas Pelayanan & 104 & 12 & 25 & 20,50 & 3,396 \\
\hline Ketegasan Sanksi & 104 & 12 & 25 & 19,77 & 3,209 \\
\hline $\begin{array}{l}\text { Modernisasi Sistem } \\
\text { Administrasi } \\
\text { Perpajakan }\end{array}$ & 104 & 32 & 55 & 44,68 & 6,504 \\
\hline Sosialisasi Perpajakan & 104 & 16 & 50 & 36,77 & 8,166 \\
\hline $\begin{array}{l}\text { Kepatuhan Wajib Pajak } \\
\text { Orang Pribadi }\end{array}$ & 104 & 15 & 25 & 21,61 & 2,934 \\
\hline
\end{tabular}

Sumber: Hasil Pengolahan Data SPSS 
Tabel 4 Hasil Analisis Koefisien Korelasi

\begin{tabular}{cccc}
\hline Model & $\mathbf{R}$ & $\mathbf{R}$ Square & Adjusted $\mathbf{R}$ Square \\
\hline 1 & 0,440 & 0,193 & 0,143 \\
\hline
\end{tabular}

Sumber: Hasil Pengolahan Data SPSS

Nilai $\mathrm{R}$ dalam model adalah sebesar 0,440 . Nilai $R$ tersebut lebih kecil dari 0,5 . Sehingga, dapat disimpulkan bahwa hubungan atau korelasi antara variabel dependen yaitu kepatuhan wajib pajak orang pribadi dengan variabel independen yaitu pemahaman, kesadaran, kualitas pelayanan, ketegasan sanksi, modernisasi sistem administrasi perpajakan dan sosialisasi perpajakan adalah sedang dan positif.

Hasil adjusted $R$ square dalam penelitian yaitu 0,143 dimana menyatakan bahwa secara statistik besarnya variabel dependen yaitu kepatuhan wajib pajak orang pribadi yang dapat dijelaskan oleh variasi variabel independen yaitu pemahaman, kesadaran, kualitas pelayanan, ketegasan sanksi, modernisasi sistem administrasi perpajakan, dan sosialisasi perpajakan adalah sebesar 0,143 atau $14,3 \%$. Sementara itu, variasi variabel lain yang tidak masuk ke dalam model regresi menjelaskan sebesar $85,7 \%$.

Uji $F$ yang ditunjukkan dalam penelitian ini, nilai sig. menunjukkan nilai sebesar 0,002 yang berarti lebih kecil dari 0,05 sehingga dapat diketahui model yang diuji merupakan model yang fit atau layak digunakan dalam model penelitian. Hasil dari uji $t$ dalam penelitian ini dapat dijelaskan sebagai berikut:

Tabel 5 Hasil Uji t

\begin{tabular}{lcc}
\hline \multicolumn{1}{c}{ Variabel } & B & Sig. \\
\hline \multicolumn{1}{c}{ (Constant) } & 11,721 & 0,000 \\
Pemahaman & 0,111 & 0,393 \\
Kesadaran & $-0,044$ & 0,722 \\
Kualitas Pelayanan & 0,018 & 0,867 \\
Ketegasan Sanksi & 0,111 & 0,314 \\
Modernisasi Sistem Administrasi & 0,162 & 0,012 \\
Perpajakan & & \\
Sosialisasi Perpajakan & $-0,033$ & 0,424 \\
\hline
\end{tabular}

Sumber: Hasil Pengolahan Data SPSS

Pemahaman menunjukkan nilai sig. 0,393 yaitu sig lebih besar dari 0,05 . Hasil ini menunjukkan bahwa $\mathrm{Ha}_{1}$ tidak dapat diterima, sehingga tidak terdapat pengaruh pemahaman terhadap kepatuhan wajib pajak orang pribadi.

Kesadaran menunjukkan nilai sig. 0,722 yaitu sig lebih besar dari 0,05 . Hasil ini menunjukkan bahwa $\mathrm{Ha}_{2}$ tidak dapat diterima, sehingga tidak terdapat pengaruh kesadaran terhadap kepatuhan wajib pajak orang pribadi.

Kualitas pelayanan menunjukkan nilai sig. 0,867 yaitu sig lebih besar dari 0,05. Hasil ini menunjukkan bahwa $\mathrm{Ha}_{3}$ tidak dapat diterima, sehingga tidak terdapat pengaruh kualitas pelayanan terhadap kepatuhan wajib pajak orang pribadi.

Ketegasan sanksi menunjukkan nilai sig. 0,314 yaitu sig lebih besar dari 0,05 . Hasil ini menunjukkan bahwa $\mathrm{Ha}_{4}$ tidak dapat diterima, sehingga tidak terdapat pengaruh ketegasan sanksi terhadap kepatuhan wajib pajak orang pribadi.

Modernisasi sistem administrasi perpajakan menunjukkan nilai sig. 0,012 yaitu sig lebih kecil dari 0,05. Hal ini menunjukkan bahwa $\mathrm{Ha}_{5}$ dapat diterima, sehingga terdapat 
pengaruh modernisasi sistem administrasi perpajakan terhadap kepatuhan wajib pajak orang pribadi.

Sosialisasi perpajakan menunjukkan nilai sig. 0,424 yaitu sig lebih besar dari 0,05 . Hal ini menunjukkan bahwa $\mathrm{Ha}_{6}$ tidak dapat diterima, sehingga tidak terdapat pengaruh sosialisasi perpajakan terhadap kepatuhan wajib pajak orang pribadi.

\section{PENUTUP}

Hasil penelitian ini menunjukkan bahwa modernisasi berpengaruh terhadap kepatuhan wajib pajak orang pribadi. Sementara itu, tidak terdapat pengaruh pemahaman, kesadaran, kualitas pelayanan, ketegasan sanksi, dan sosialisasi perpajakan terhadap kepatuhan wajib pajak orang pribadi. Penelitian yang terbatas pada satu wilayah, masalah yang muncul pada uji heteroskedastisitas atas variabel modernisasi sistem administrasi perpajakan, serta dugaan pengaruh variabel independen lain yang tidak terdapat dalam penelitian ini merupakan keterbatasan dalam penelitian ini. Rekomendasi yang dapat diberikan ialah untuk peneliti selanjutnya diharapkan dapat memperluas cakupan wilayah penelitian, dapat mengatasi masalah yang muncul dalam uji heteroskedastisitas yang dialami di penelitian ini, serta dapat menambahkan variabel independen lain yang tidak terdapat dalam penelitian ini seperti tarif pajak, keadilan perpajakan, kemudahan pengisian SPT agar nilai adjusted $R$ square dapat lebih tinggi dibandingkan penelitian saat ini.

\section{REFERENCES:}

Ananda, Pasca Rizki Dwi, Srikanda Kumandji, dan Achmad Husaini. 2015. Pengaruh Sosialisasi Perpajakan, Tarif Pajak, dan Pemahaman Perpajakan terhadap Kepatuhan Wajib Pajak (Studi pada UMKM yang terdaftar sebagai Wajib Pajak di Kantor Pelayanan Pajak Pratama Batu). Jurnal Mahasiswa Perpajakan, 6(2).

Arifah, Arifah, Rita Andini, dan Kharis Raharjo. 2017. Pengaruh Modernisasi Sistem Administrasi Perpajakan, Kualitas Pelayanan, Pengetahuan Perpajakan, Sanksi Perpajakan dan Kesadaran Perpajakan terhadap Kepatuhan Wajib Pajak Orang Pribadi pada Kantor Pelayanan Pajak Pratama Demak selama periode (2012-2016). Journal of Accounting Universitas Pandanaran Semarang, 3, 1-16.

Astina, I putu Surya dan Putu Ery Setiawan. 2018. Pengaruh Pemahaman Peraturan Perpajakan, Kualitas Pelayanan Fiskus, dan Kesadaran Wajib Pajak terhadap Kepatuhan WPOP. E-Jurnal Akuntansi Universitas Udayana, 23(1), 1-30.

Brata, Dio Januar, Isna Yuningsih, dan Agus Iwan Kesuma. 2017. Pengaruh Kesadaran Wajib Pajak, Pelayanan Fiskus dan Sanksi Pajak terhadap Kepatuhan Wajib Pajak Orang Pribadi yang melakukan Kegiatan Usaha dan Pekerjaan Bebas di Kota Samarinda. E-Jurnal Forum Ekonomi, 10(1).

Hardiningsih, Pancawati. 2011. Faktor-Faktor yang Mempengaruhi Kemauan Membayar Pajak. Jurnal Dinamika Keuangan dan Perbankan. Studi Akuntansi Universitas Stikubank Semarang, 3(1), 126-142.

Herryanto, Marisa dan Agus Arianto Toly. 2013. Pengatuh Kesadaran Wajib Pajak, Kegiatan Sosialisasi Perpajakan dan Pemeriksaan Pajak terhadap Penerimaan Pajak Penghasilan di KPP Pratama Surabaya Sawahan. Tax and Accounting Review, 1(1), 124-135.

Jotopurnomo, Cindy dan Yenni Mangoting. 2013. Pengaruh Kesadaran Wajib Pajak, Kualitas Pelayanan Fiskus, Sanksi Perpajakan, Lingkungan Wajib Pajak terhadap Kepatuhan Wajib Pajak Orang Pribadi di Surabaya. Tax and Accounting Review, 1(1), 49-54.

Kurniawan, Irfan. 2018. Pengaruh Modernisasi Sistem Administrasi Perpajakan, Sanksi Perpajakan Terhadap Kepatuhan Wajib Pajak Orang Pribadi (Studi Kasus pada KPP Pratama Magelang). Jurnal Ekobis Dewantara, 1(3). 
Lianty, R. A. Meiska dan Dini Wahjoe Hapsati. 2017. Pengetahuan Perpajakan, Sosialisasi Perpajakan dan Pelayanan Fiskus Terhadap Kepatuhan Wajib Pajak. Jurnal Riset Akuntansi Kontemporer, 9(2), 55-65.

Lubis, Reza Hanafi. 2017. Pengaruh Kualitas Pelayanan Perpajakan, Sanksi Perpajakan Terhadap Kepatuhan Wajib Pajak di KPP Pratama Medan Belawan. Jurnal Konsep Bisnis dan Manajemen, 4(1), 31-41.

Lydiana. 2018. Pengaruh Kesadaran Wajib Pajak, Pengetahuan Pajak dan Sanksi Pajak terhadap Kepatuhan Wajib Pajak Orang Pribadi di KPP Pratama Surabaya Gubeng. Jurnal IImiah Mahasiswa Universitas Surabaya, 7(1), 125-133.

Mardiasmo. 2016. Perpajakan Edisi Revisi. Yogyakarta: Andi.

Masruroh, Siti dan Zualikha. 2013. Pengaruh Pemahaman NPWP, Pemahaman Wajib Pajak, Kualitas Pelayanan, Sanksi Perpajakan Terhadap Kepatuhan Wajib Pajak (Studi Empiris Pada WPOP di Kabupaten Tegal). Dipenogoro Journal of Accounting, 2(4), 1-15.

Najib, Debbi Farihun. 2013. Analisis Faktor-Faktor Yang Mempengaruhi Kepatuhan Wajib Pajak Orang Pribadi Dalam Membayar Pajak Penghasilan (Studi Pada Wajib Pajak Orang Pribadi KPP Pratama Malang Utara). Program Studi Akuntansi Universitas Brawijaya Malang.

Naufal, Muhammad Faris dan Putu Ery Setiawan. 2018. Pengaruh Sosialisasi Perpajakan, Pemahaman Prosedur Perpajakan, Umur, Jenis Pekerjaan Terhadap Kepatuhan Wajib Pajak Orang Pribadi. E-Journal Akuntansi Universitas Udayana, 25(1), 241-271.

Nindya, Yunita Kumala dan Nurharibnu Wibisono. 2019. Pengaruh Sikap Wajib Pajak, Pengetahuan Pajak, dan Sosialisasi Pajak Terhadap Kepatuhan Wajib Pajak di Kantor Pelayanan Pajak Pratama Jember. Jurnal IImu Ekonomi, Manajemen dan Akuntansi, 8(1), 1-9.

Rahayu, Siti Kurnia. 2017. PERPAJAKAN INDONESIA: Konsep dan Aspek Formal, Bandung: Rekayasa Sains.

Rahayu, Sri dan Ita Salsani Lingga. 2009. Pengaruh Modernisasi Sistem Administrasi Perpajakan Terhadap Kepatuhan Wajib Pajak. Jurnal Akuntansi, 1(2), 119-138.

Sarunan, Widya, K. 2015. Pengaruh Modernisasi Sistem Administrasi Perpajakan Terhadap Kepatuhan Wajib Pajak Orang Pribadi dan Wajib Pajak Badan Pada Kantor Pelayanan Pajak Pratama Manado. Jurnal EMBA, 3(4), 518-526.

Siahaan, Stefani dan Halimahtusyadiah. 2018. Pengaruh Kesadaran Perpajakan, Sosialisasi Perpajakan, Pelayanan Fiskus, dan Sanksi perpajakan Terhadap Kepatuhan Wajib Pajak Orang Pribadi. Jurnal Akuntansi dan Bisnis, 8(1), 1-13.

Susmiatun dan Kusmuriyanto. 2014. Pengaruh Pengetahuan Perpajakan, Sanksi Perpajakan dan Keadilan Perpajakan terhadap Kepatuhan Wajib Pajak UMKM di Kota Semarang. Accounting Analysis Journal, 3(1), 378-386.

Tahar, Afrizal dan Arnain Kartika Rachman. 2014. Penagruh Faktor Internal dan Faktor Eksternal terhadap Kepatuhan Wajib Pajak. Jurnal Akuntansi dan Investasi, 15(1), 57-67.

Tiraada, Tryana A. M. 2013. Kesadaran Perpajakan, Sanksi Pajak, Sikap Fiskus terhadap Kepatuhan WPOP Di Kabupaten Minahasa Selatan. Jurnal Fakultas Ekonomi dan Bisnis, Jurusan Akuntansi, 1(3), 999-1008.

Utari, Gusti Ayu Kade Dewi, Luh Kade Datrini dan Ni Nengah Seri Ekayani. 2020. Pengaruh Modernisasi Sistem Administrasi perpajakan dan Kesadaran Wajib Pajak pada Kepatuhan Wajib Pajak Orang Pribadi di KPP Pratama Tambanan. Jurnal Riset akuntansi Warmadewa, 1(1), 34-39.

Wardani, Dewi Kusuma dan Erna Wati. 2018. Pengaruh Sosialisasi Perpajakan Terhadap Kepatuhan Wajib Pajak dengan Pengetahuan Perpajakan sebagai Variabel Intervening (Studi Pada WPOP di KPP Pratama Kebumen). Jurnal Nominal, 7(1), 33-54.

Winerungan, Oktaviane Lidya. 2013. Sosialisasi Perpajakan, Pelayanan Fiskus, dan Sanksi Perpajakan terhadap Kepatuhan WPOP di KPP Manado dan KPP Bitung. Jurnal Ekonomi dan Pembangunan, 1(3), 960-970.

Yusnidar, Johan Sunarti dan Arik Prasetya. 2015. Pengaruh Faktor-Faktor Yang Mempengaruhi Kepatuhan Wajib Pajak Dalam Melakukan Pembayaran Pajak Bumi dan Bangunan Pedesaan dan Perkotaan (Studi pada Wajib Pajak PBB-P2 Kecamatan Jombang Kabupaten Jombang). Jurusan Administrasi Bisnis Universitas Brawijaya, Jurnal Perpajakan, 1(1), 1-10. 
